\title{
Instagram sebagai Medium Komunikasi Risiko di Masa Pandemi COVID-19: Studi Netnografi terhadap Komunitas Online KawalCOVID19.id
}

\section{Instagram as a Medium of Risk Communication in COVID-19 Pandemic: A Netnography Study of Virtual Community KawalCOVID19.id)}

\author{
Annisa Damayanti ${ }^{1, *}$, Kapat Yuriawan ${ }^{2)}$ \\ ${ }^{1}$ Institut Pertanian Bogor, Bogor 16680, Indonesia \\ ${ }^{2}$ Biro Kerjasama Hukum dan Humas-LIPI, Jakarta 12710, Indonesia \\ E-mail korespondensi: dama180193annisa@apps.ipb.ac.id \\ Diterima: 31 Agustus $2020 \quad$ Direvisi: 25 November $2020 \quad$ Disetujui: 26 November $2020 \quad$ Publikasi Online: 5 Desember 2020
}

\section{ABSTRACT}

Social media has played a significant role during the COVID-19 pandemic as it enables people to share news, personal experiences and perspectives with each other in real-time and globally. Kawalcovid19.id is a virtual community that disseminates accurate information about COVID-19 amidst the flood of information in Indonesian society. Thenature two-way communication of social media makes risk communication successful, where there is an exchange of information between experts and the public about risks and their management of risky situations so that they can make the right decisions to protect themselves. This study aims to analyze the trend of risk communication on the Instagram account@ kawalcovid19.id, the communication function carried out by the community as an agent of social movements, and the public's understanding of risk communication. This research uses a netnographic study method. The results showed that risk communication delivered through content got positive and interactive reactions from netizens, their interest was seen to be higher in content produced in the form of infographics with informative message content compared to educational ones. Informative messages containing updates case, appeals for health protocols, government policy information, and information related to worship. This study shows that risk communication will be effectively delivered via Instagram using infographic and informative content.

Key words: Instagram, netnography, risk communication, virtual community

\section{ABSTRAK}

Media sosial berperan signifikan selama pandemi COVID-19 sebab memungkinkan orang untuk berbagi berita, pengalaman pribadi dan sudut pandang satu sama lain secara real-time dan global. Kawalcovid19.id merupakan komunitas virtual yang menyebarkan informasi seputar COVID-19 yang akurat ditengah banjir informasi di masyarakat Indonesia. Sifat Two way communication dari media sosial membuat komunikasi risiko berhasil, di mana terjadi pertukaran informasi diantara para ahli dan masyarakat mengenai risiko dan managemennya atas situasi berisiko yang dihadapi sehingga dapat mengambil keputusan yang tepat untuk melindungi diri. Penelitian ini bertujuan untuk menganalisis tren komunikasi risiko pada akun Instagram @kawalcovid19.id, fungsi komunikasi yang dijalankan komunitas sebagai agen gerakan sosial, dan pemaknaan khalayak terhadap komunikasi risiko yang dilakukan. Penelitian ini menggunakan metode studi netnografi. Hasil penelitian menunjukkan bahwa komunikasi risiko yang disampaikan melalui konten mendapatkan reaksi yang positif dan interaktif dari warganet, minat mereka terlihat lebih tinggi kepada konten yang diproduksi dalam bentuk infografis dengan isi pesan yang bersifat informatif dibandingkan yang edukatif. Pesan informatif berisi update kasus, himbauan protokoler kesehatan, informasi kebijakan pemerintah, dan informasi terkait ibadah. Kajian ini memperlihatkan bahwa komunikasi risiko akan efektif disampaikan melalui Instagram menggunakan konten infografis dan bersifat informatif.

Kata kunci: Instagram, komunikasi risiko, komunitas virtual, netnografi

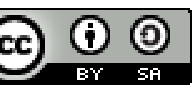

Content from this work may be used under the terms of theCreative Commons Attribution-ShareAlike 4.0

International. Any further distributionof this work must maintain attribution to the author(s) and the title of the work, journal citation and DOI.

Published under Department of Communication and Community Development Science, IPB University and in association with Forum Komunikasi Pembangunan Indonesia and Asosiasi Penerbitan Jurnal Komunikasi Indonesia.

E-ISSN: 2442-4102 | P-ISSN: 1693-3699 


\section{PENDAHULUAN}

Media sosial kini menjadi wahana penyebaran informasi, edukasi, dan entertainment oleh masyarakat kepada masyarakat. Di tengah kondisi pandemi COVID-19 yang mengharuskan masyarakat melakukan social distancing dan lockdown, menjadikan mereka semakin beralih ke media social untuk mendapatkan dukungan, hiburan, dan tetap terhubung dengan orang lain (Nabity-Grover et al., 2020). Media sosial memainkan peran yang signifikan selama pandemi sebab memungkinkan orang untuk berbagi berita serta pengalaman pribadi dan sudut pandang satu sama lain secara real-time dan global (Islam et al., 2020).

Pengguna aktif media sosial di Indonesia mencapai 59\% dari total populasi dunia, dan khusus untuk pengguna Instagram, Indonesia menjadi negara keempat terbesar di dunia dengan usia pengguna tertinggi berada pada rentang 18-34 tahun (Hootsuite, 2020). Akun official pemerintah dan stakeholder banyak tersedia di Instagram, dan banyak dari mereka yang menyebarkan informasi seputar COVID19 melalui postingan konten-kontennya. Penyebaran informasi COVID-19 di Instagram, seperti dijelaskan oleh penelitian di Iran (Niknam et al., 2020), menemukan bahwa pengguna akun Instagram menggunakan berbagai strategi dalam membuat konten tentang krisis kesehatan masyarakat, sebanyak 23 tema muncul yang meliputi epidemiologi dan statistik, pelatihan dan perawatan, pedoman pencegahan umum, kebersihan, pola makan dan gaya hidup sehat, pasien, diagnosis dan pengobatan, alat pelindung diri, pengobatan tradisional, psikologi, anak-anak, aspek budaya, dampak sosial budaya, agama, informasi yang salah dan perilaku yang salah, hewan, sindiran, kondisi sistem perawatan kesehatan, politik, karantina, dampak ekonomi, dan berita dunia, yang mana semua tema tersebut berguna dalam memberikan wawasan baru dan realistis tentang krisis yang sedang terjadi dan mengidentifikasi topik yang menjadi perhatian publik sehingga dapat membantu pembuatan kebijakan dengan mengidentifikasi masalah paling kritis dari perspektif publik dan memanfaatkannya dalam mengelola pandemi yang sedang berlangsung maupun yang akan datang. Tak hanya itu, penelitian oleh (Dabbagh, 2020) juga menemukan bahwa Instagram menjadi media kampanye yang dinilai efektif dan murah dalam mengedukasi masyarakat untuk mencegah penyebaran virus melalui mencuci tangan secara teratur, di mana kampanye dalam Instagram ini mendapat banyak feedback positif dari followers.

Banyak kajian tentang media sosial telah dilakukan selama krisis kesehatan pandemi COVID-19 ini, kajian tersebut umumnya seputar topik; diseminasi informasi kesehatan (Abdoli \& Heidarnejadi, 2020; Apuke \& Omar, 2020; Barua et al., 2020; Islam et al., 2020; Kaya, 2020; Merchant \& Lurie, 2020; Moran, 2020; Tsui et al., 2020), kesehatan mental (Gao et al., 2020; Lin et al., 2020; Nabity-Grover et al., 2020; Naeem, 2021; Zhong et al., 2021), sentiment di media social (Bhat et al., 2020; Chakraborty et al., 2020), serta dukungan sosial dan manajemen pandemi melalui media sosial (Carlos et al., 2020; Li \& Zhang, 2020).

Namun, dari banyaknya kajian tersebut, hanya sedikit yang mengkajinya dalam perspektif komunikasi risiko, di mana hal tersebut penting untuk dikaji dalam situasi seperti sekarang ini. Komunikasi risiko merupakan pertukaran informasi real-time, saran dan pendapat antara para ahli, masyarakat dan berbagai pihak lain yang berkepentingan mengenai risiko serta faktor-faktor yang berkaitan dengan risiko, yang bertujuan untuk memungkinkan orang yang berisiko mengambil keputusan yang tepat untuk melindungi diri mereka sendiri dan orang yang mereka cintai (WHO, 2020).

Penelitian (Wang et al., 2020) menemukan bahwa selama pandemi COVID-19 media sosial berperan penting bagi badan kesehatan masyarakat dan stakeholders untuk menyebarkan informasi mengenai situasi, risiko, dan tindakan perlindungan pribadi yang menghambat penyebaran penyakit, namun sebaliknya, terdapat sikap meremehkan risiko pandemi di awal krisis, dari analisis tweet lembagalembaga tersebut teridentifikasi ketidakcukupan, ketidaksesuaian, dan ketidakkonsistenan pada jenis pesan-pesan penting yang disampaikan. Kemudian, (Chatterjee et al., 2020) juga menemukan bahwa kesadaran risiko adalah cara terbaik untuk mencegah dan memperlambat penularan pandemi COVID19, yang dapat dicapai melalui komunikasi penilaian risiko, di mana komunikasi risiko yang efektif merupakan langkah penting untuk mengendalikan infodemik. Pentingnya penggunaan media sosial sebagai alat komunikasi risiko juga disampaikan oleh (Abrams \& Greenhawt, 2020) dalam penelitiannya yang menjelaskan bahwa media sosial adalah cara potensial untuk memastikan komunikasi risiko berjalan dengan tepat, karena publik sangat bergantung pada media dan hubungan sosial untuk menginformasikan tingkat persepsi risiko mereka. Seperti yang dijelaskan penelitian yang 
dilakukan di Jepang oleh (Parady et al., 2020) menemukan bahwa persepsi risiko yang diukur sebagai ketakutan terhadap COVID-19, berkaitan dengan probabilitas lebih tinggi dalam membatasi diri untuk makan di luar dan bersantai.

Akun Instagram@kawalcovid19.id merupakan salah satu komunitas virtual yang peduli terhadap penyebaran informasi COVID-19 di Indonesia, yang dibentuk karena keprihatinan atas kesimpangsiuran informasi yang beredar mengenai COVID-19 di Indonesia. Komunitas ini terdiri dari sekumpulan profesional yang pro data dan berlatar belakang medis, edukasi, sains, riset, teknologi dan komunikasi massa. Oleh karena itu, topik komunikasi risiko sesuai untuk dikaji dalam aktivitas komunitas virtual ini.

Berdasarkan penjelasan diatas, maka penelitian ini akan menjadi pengembangan dari penelitian sebelumnya mengenai penggunaan media sosial dalam perspektif komunikasi risiko di tengah pandemi COVID-19. Penelitian ini berfokus untuk mengkaji penggunaan media sosial Instagram dalam hal ini adalah akun komunitas virtual @kawalcovid19.id sebagai medium dalam penyampaian komunikasi risiko COVID-19 kepada masyarakat Indonesia. Secara khusus, kajian penelitian ini adalah untuk melihat; (1) bagaimana tren komunikasi risiko komunitas peduli COVID19 oleh akun @kawalcovid19.id, (2) bagaimana fungsi komunikasi (informasi, edukasi, advokasi) yang dijalankan oleh komunitas@kawalcovid19.id sebagai agen gerakan social, (3) bagaimana pemaknaan khalayak terhadap komunikasi risiko yang dilakukan.

\section{METODE}

Penelitian ini menggunakan paradigma konstruktivis. (Creswell, 2013), menjelaskan bahwa paradigma ini mengasumsikan individu selalu berusaha memahami dunia di mana mereka hidup dan bekerja. Mengembangkan makna-makna subjektif atas pengalaman mereka, makna yang diarahkan pada objek atau benda tertentu. Metode yang digunakan dalam penelitian ini adalah deskriptif kualitatif melalui pendekatan studi netnografi. Metode ini dilakukan untuk mengeksplorasi dan memahami makna tentang suatu fenomena berdasarkan pandangan partisipan, dan menggambarkan secara tepat sifat-sifat individu, keadaan, gejala atau kelompok tertentu (Creswell, 2013).

Netnografi adalah sebuah metode penelitian kualitatif, bentuk terbaru dari penelitian etnografi, yang mempelajari kebiasaan unik dari berbagai jenis komunitas dan budaya yang terjadi dalam komunikasi termediasi komputer atau online (Kozinets, 2019). Komunitas online diartikan sebagai sekelompok individu yang berbagi interaksi sosial dan ikatan sosial yang terjalin dalam komunikasi termediasi komputer atau ruang virtual. Netnografi digunakan untuk mempelajari dan memahami dunia cyber dan perilaku komunitas online, mendalami kehidupan komunitas virtual tersebut dari perspektif pelaku (Handini, 2018; Samatan et al., 2017). Objek kajian netnografi adalah warganet dengan aktivitas dan kehidupan mereka di dunia virtual.

Subyek dari penelitian ini adalah warganet yang memberikan komentar terhadap konten media sosial Instagram KawalCOVID19. Sedangkan obyek dari penelitian ini adalah media sosial Instagram yang dimiliki oleh KawalCOVID19 dalam mendiseminasikan informasi kepada masyarakat. Penelitian ini menganalisa tentang komunikasi risiko yang dilakukan oleh akun KawalCOVID19. yang dilakukan dengan cara memposting beberapa informasi, himbauan, serta klarifikasi yang dikemas melalui infografis maupun gambar kartun. Hal tersebut bertujuan untuk memberikan gambaran situasi terkini betapa berbahayanya wabah ini sehingga masyarakat semakin sadar dan mentaati protokol kesehatan yang telah ditetapkan oleh pemerintah.

Penelitian ini menggunakan data primer dan sekunder. Teknik pengumpulan data primer dalam penelitian ini dilakukan dengan cara mengamati komentar, like, dan share dari media Instagram yang dimiliki oleh komunitas online KawalCOVID19, sementara data sekunder diperoleh melalui studi literatur berupa jurnal ilmiah dan buku-buku yang relevan dengan tema penelitian. Menurut (Kozinets, 2019) peneliti komunitas virtual menggunakan media komputer yang memiliki fasilitas internet dan melakukan teknik pengumpulan data dalam ruang maya, mengambil/mengunduh informasi dari website yang berkaitan dengan penelitian, dan mengamati ruang maya (website) sebagai tempat berkumpulnya para anggota komunitas maya. Selanjutnya, teknik analisis data dalam penelitian ini dilakukan dengan cara menganalisa konten dan respon yang diberikan warganet mulai dari posting pertama tanggal 6 Maret 2020 sampai dengan 22 April 2020. 


\section{HASIL DAN PEMBAHASAN}

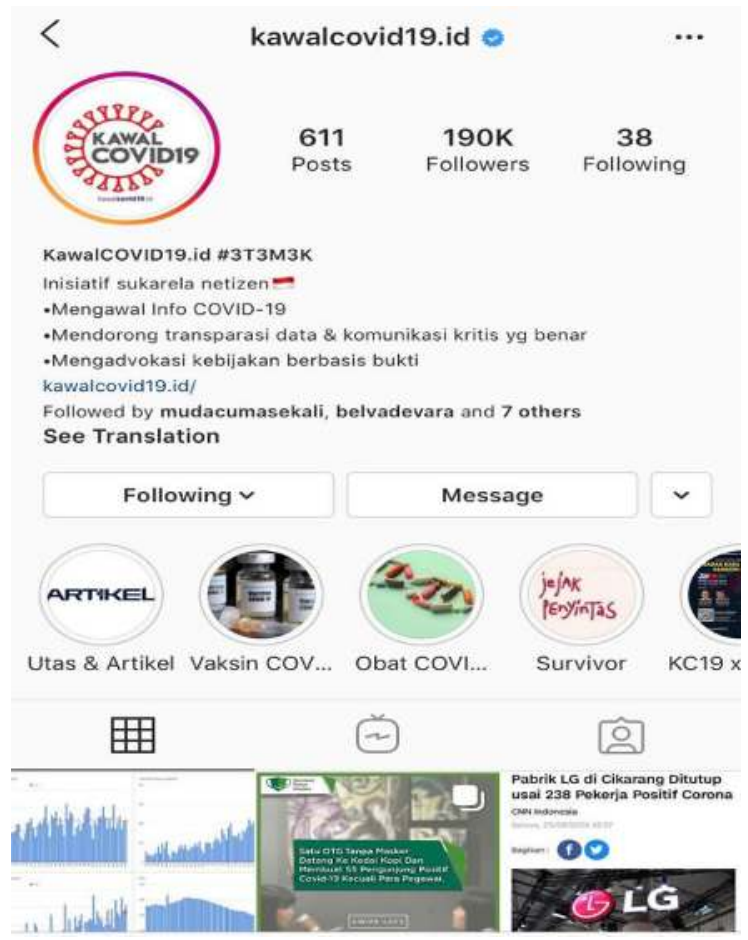

Gambar 1. Akun Instagram Komunitas Virtual KawalCOVID19.id

\section{Tren Komunikasi Risiko Komunitas Peduli COVID19}

Komunikasi risiko merupakan pertukaran informasi real-time, saran dan pendapat antara para ahli dan orang yang menghadapi ancaman terhadap kesehatan mereka, ekonomi atau kesejahteraan sosial (Abrams \& Greenhawt, 2020). Komunikasi risiko menjadi suatu pendekatan terhadap pengendalian risiko secara sosial oleh instansi terkait dengan tujuan menginformasikan, mendidik dan membantu pembuatan keputusan (Harlina et al., 2018). Komunikasi risiko yang dilakukan oleh komunitas virtual ini dibuat dalam bentuk konten-konten yang di post di media sosial Instagram. Tren komunikasi risiko didapatkan melalui total respon warganet dalam fitur Like, Comment, dan Share yang tersedia pada Instagram. Posting konten dilakukan setiap hari dengan jumlah post minimal satu konten per hari.

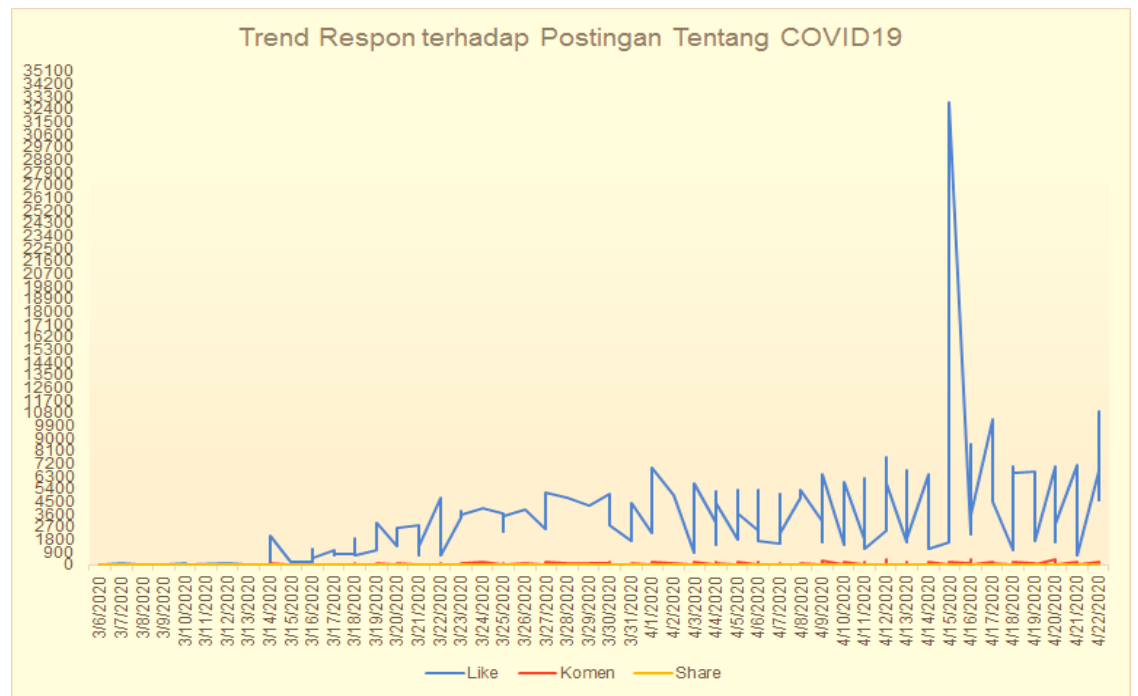

Gambar 2. Tren Respon Warganet Atas Konten Komunikasi Risiko (Maret - April 2020) 
Berdasarkan pengamatan konten yang di post selama periode penelitian, respon warganet yang terlihat melalui fitur like, comment, dan share Instagram, menunjukkan grafik yang fluktuatif. Reaksi terbanyak atas post adalah dari fitur Like, sementara fitur comment dan share kurang mendapatkan reaksi warganet. Terdapat satu konten yang mendapatkan reaksi Like terbesar dengan persentase tertinggi yang di post pada tanggal 15 April 2020, konten ini mendapatkan Like sebanyak 32.888 dan mendapatkan komentar sebanyak 221. Konten tersebut menampilkan gambar kartun manga tenaga medis yang menggunakan APD (alat pelindung diri), pesan komunikasi dalam konten ini adalah tentang upaya tenaga medis dalam menjaga dirinya melalui protokol kesehatan medis ketika menangani pasien di tengah pandemi COVID-19. Terdapat narasi pendek bersambung dari setiap potongan gambar manga yang diberikan, narasi tersebut adalah "Kalau ini cuma flu biasa, terus ngapain kami para nakes capek-capek, repot-repot, pakai baju beginian, kami melakukan ini supaya bisa efektif selamatkan nyawa, jadi jujurlah pada kami tentang kondisi anda supaya kami bisa pulang dengan selamat ke keluarga kami". Narasi ini berisi edukasi untuk masyarakat dan himbauan untuk jujur pada tenaga medis dan juga ajakan untuk tidak meremehkan COVID19.

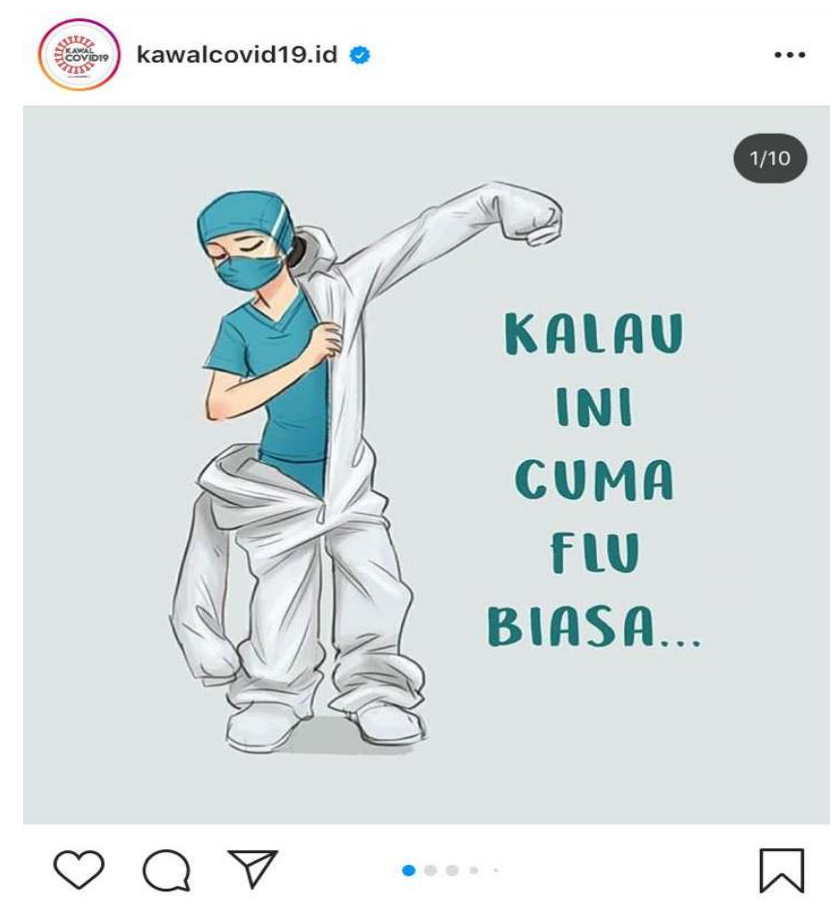

Gambar 3. Konten 15 April 2020

Konten ini dibuat dalam bentuk infografis, Slide gambar kartun manga bersambung yang menarik, dan kalimat pendek di setiap Slide gambar. Narasi yang disampaikan pada gambar konten ini didasarkan pada kejadian nyata di lapangan ketika banyak berita terkait penularan kasus kepada dokter melalui pasien dikarenakan informasi yang diberikan pasien saat pemeriksaan medis tidak jujur, seperti informasi tentang riwayat perjalanan yang menimbulkan risiko tinggi tertular COVID-19. Seperti yang dijelaskan oleh (Wicandra, 2006) kode-kode visual yang terpaparkan dalam infografis memberikan realita objektif berdasarkan fakta yang terjadi. Infografis memuat mode semiotika melalui teks, warna, dan gambar yang mengandung makna atas pesan yang disampaikan oleh pencipta kepada audiens, masyarakat.

Penggalan kalimat di setiap Slide gambar, memberikan makna penegasan atas pesan yang disampaikan. Setiap penggalan kalimat ditampilkan bersamaan dengan gambar yang menyesuaikan dengan kalimat yang diberikan, sehingga terkesan bahwa kalimat tersebut dikuatkan oleh gambar yang ditampilkan. Menurut (Krum, 2013) tujuan infografis sama dengan public speaking, yaitu menginformasikan, menghibur dan mempersuasi audiens sehingga audiens memberikan atensi, menyempatkan untuk membaca, menyimpulkan dan melakukan aksi sesuai apa yang ada di dalam infografis. Perlakuan media visual terbukti mampu memberikan efek berupa peningkatan pemahaman informasi, persepsi risiko dan sikap terhadap pencegahan penyakit, di mana media visual yang paling 
efektif untuk meningkatkan persepsi risiko dan sikap adalah komik manga (Nasution et al., 2018). Hal ini juga terlihat dari konten dengan respon tertinggi tersebut di mana terdapatnya penggunaan gambar animasi atau manga dalam infografisnya.

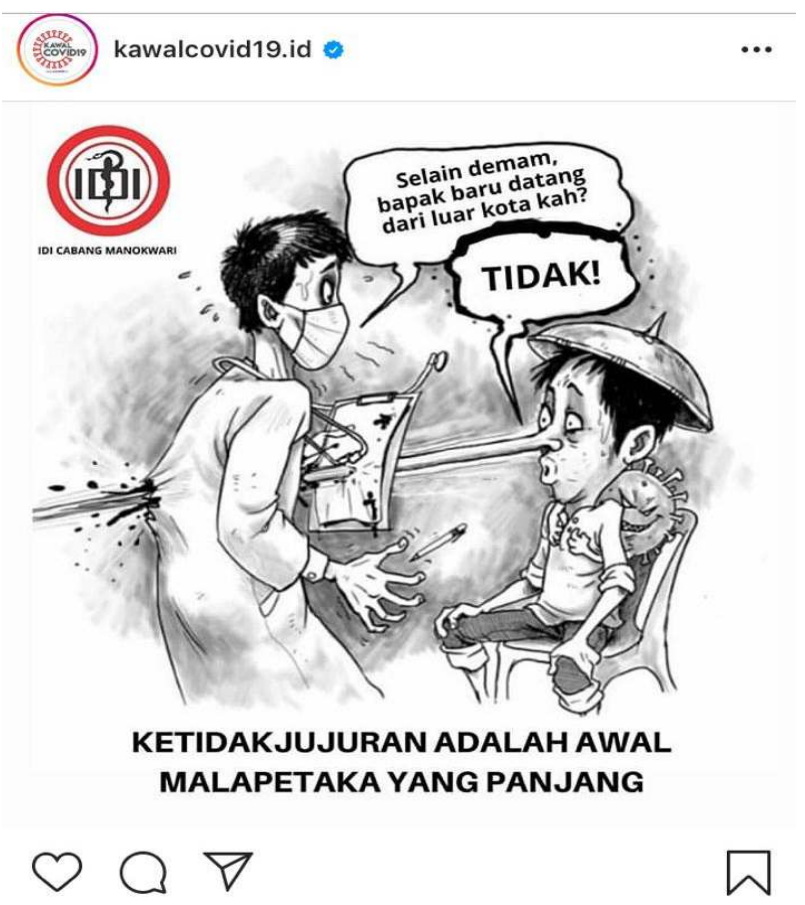

Gambar 4. Konten 17 April 2020

Kemudian, respon warganet atas konten selanjutnya yang mendapatkan persentase Like cukup tinggi terjadi pada konten yang di post tanggal 17 April 2020, dengan total Like sebanyak 10.423 dan 223 komentar. Konten ini masih berkaitan dengan konten yang dibahas sebelumnya, mengenai tenaga medis dan kesediaan jujur dari pasien jika mengalami gejala COVID-19 agar dapat ditindak sesuai dengan protokol kesehatan untuk mencegah penularan dan peningkatan grafik angka pasien COVID19. Konten ini dibuat oleh IDI (Ikatan Dokter Indonesia) Manokwari dalam bentuk gambar manga dan penggalan percakapan antara dokter dan pasien, dengan narasi besarnya adalah "Ketidakjujuran adalah awal malapetaka yang panjang".

Penting bagi masyarakat mengetahui bagaimana mengatasi persoalan kesehatan yang terjadi saat ini. Kontribusi masyarakat dan tenaga medis diharapkan dapat terjadi dalam bentuk kerja sama yang baik, dan keterbukaan menjadi hal yang krusial. Hal ini pun disadari dan disetujui oleh sebagian masyarakat yang terlihat dari respon Like yang cukup banyak diberikan pada konten ini. Publikasi sosial media saat ini menjadi suatu bentuk strategi komunikasi untuk meningkatkan kesehatan. Menurut (Rahmadiana, 2012), tidak ada jalan lain menyukseskan kesehatan individu dan masyarakat kecuali dengan memanfaatkan jasa komunikasi, semua analisis dan upaya untuk meningkatkan kualitas hidup manusia harus melibatkan peranan ilmu komunikasi, terutama strategi komunikasi, untuk menyebarluaskan informasi yang dapat mempengaruhi individu dan komunitas masyarakat agar dapat membuat keputusan yang tepat sehubungan dengan kesehatan mereka.

Kemudian, dari total konten yang di analisa selama periode penelitian, yaitu sebanyak 121 konten, ditemukan dua katagori isi konten, yaitu informasi dan edukasi. Dapat diketahui, berdasarkan diagram pada Gambar 5, konten informasi memiliki persentase sebanyak $65 \%$ dan konten edukasi memiliki persentase sebanyak $35 \%$. Penggunaan media sosial sangat efektif pada tahap interest dan desire, yang dipengaruhi oleh faktor kelengkapan informasi, kejelasan informasi dan daya tarik (Oktaviani \& Fatchiya, 2019). Terlihat bahwa warganet lebih banyak merespon konten pesan yang informatif dari pada pesan yang edukatif, artinya warganet lebih memperhatikan pada berita informasi dari pada berita edukasi. Konten informatif ini adalah data tentang jumlah pasien yang terdampak dan perkembangan dari penyebaran virus di Indonesia. Konten ini juga memiliki frekuensi post yang paling banyak yaitu setiap hari. 


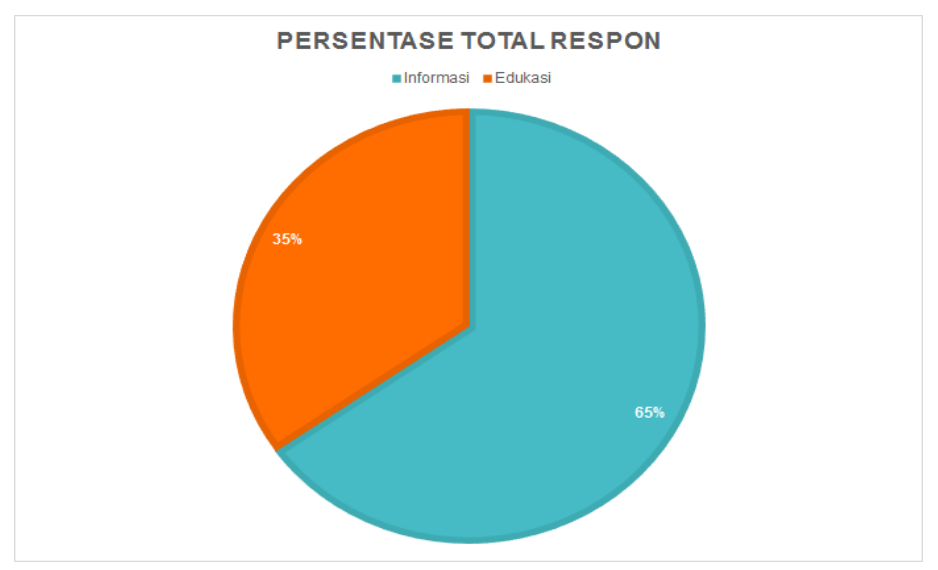

Gambar 5. Diagram Persentase Total Respon (Maret - April 2020)

Sementara, konten yang bersifat edukatif berisi tentang bagaimana tindakan-tindakan yang harus diambil selama penanganan wabah virus sesuai dengan protokoler kesehatan. (Pratiwi \& Hidayat, 2020) mengatakan permasalahan di Indonesia saat ini terkait peristiwa baru wabah COVID-19, merupakan virus baru sehingga banyak masyarakat belum tahu dan tidak mengerti cara menangani virus tersebut, banyak berita kemudian menyampaikan penanggulangan dan sosialisasi dari pemerintah, serta informasi kebijakan-kebijakan baru. Pemerintah berupaya menyampaikan informasi terkait COVID-19 melalui berbagai media massa, sehingga informasi diterima secara merata dan luas (Halik, 2013). Tujuan pemberian informasi tersebut untuk memberi efek sadar akan kesehatan dan menjaga diri dari bahaya virus, hal ini membantu memberikan pengetahuan yang luas dan menyelesaikan kepanikan atas dasar ketidaktahuan mengenai virus COVID-19 (Pratiwi \& Hidayat, 2020). Hal tersebut memberikan penjelasan mengapa warganet lebih cenderung merespon konten yang bersifat informatif. Karena ketidaktahuan atas wabah baru yang menyerang dunia ini, minat dan feedback warganet cenderung kepada berita yang berisi informasi.

\section{Fungsi Komunikasi Komunitas Peduli COVID-19 Sebagai Agen Gerakan Sosial}

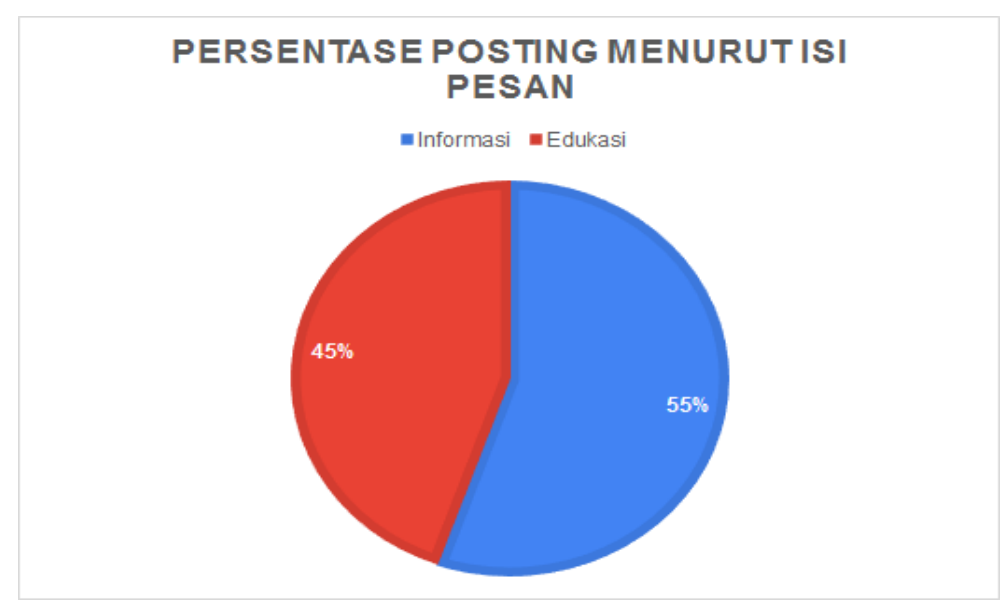

Gambar 6. Diagram Persentase Konten Menurut Isi Pesan (Maret - April 2020)

Berdasarkan diagram pada Gambar 6, dari 121 konten yang di post selama periode penelitian, sebanyak $55 \%$ isi pesan konten adalah informasi, dan sebanyak $45 \%$ berisi edukasi. Sebagaimana definisi dari komunikasi risiko itu sendiri adalah pertukaran informasi real-time, saran dan pendapat antara para ahli dan orang yang menghadapi ancaman terhadap kesehatan, ekonomi atau kesejahteraan sosial mereka yang nantinya akan membantu mereka dalam pembuatan keputusan, dan juga tujuan dari dibentuknya komunitas virtual KawalCOVID19.id ini sebagai media penyebaran informasi, maka hal ini pun terlihat dari persentase isi pesan yang mereka produksi dalam konten-konten komunikasi mereka kepada publik di jagat maya. Hal ini didukung oleh temuan penelitian dari (Triyaningsih, 2020) yang mengatakan bahwa media terutama media sosial menjadi rujukan bagi masyarakat untuk 
mendapat informasi mengenai Virus Corona, adapun efek media kepada masyarakat menunjukkan strong effect bahkan mampu membentuk persepsi masyarakat Pamekasan tentang pencegahan penularan Virus Corona kepada individu.

Pesan informasi tersebut berisi hal seputar update data kasus harian yang terjadi di Indonesia, yaitu jumlah pasien terkonfirmasi positif, pasien dalam perawatan, pasien yang dinyatakan sembuh, dan pasien yang meninggal dunia. Selain hal tersebut informasi yang diberikan juga berupa himbauan dan informasi mengenai kebijakan yang diberikan oleh pemerintah terkait COVID-19. Ada juga informasi yang berisi poster mengenai seminar dan diskusi online yang membahas mengenai wabah COVID-19, informasi mengenai website untuk melihat jadwal dan waktu ibadah secara online untuk agama nasrani, informasi mengenai dokter yang meninggal dunia saat menangani COVID-19, serta mengenai himbauan yang diberikan kepada masyarakat mengenai penggunaan masker misalnya dan protokoler kesehatan.

Sementara, pesan yang berisi edukasi adalah mengenai bagaimana menghadapi wabah, tindakan pencegahan seperti apa yang perlu dilakukan, dan pemberian pemahaman kepada masyarakat umum. Konten edukasi tersebut berisi pentingnya melakukan social distancing, cara menjaga kesehatan, dan aktivitas apa saja yang bisa dilakukan dirumah. Persentase konten menurut isinya merupakan bentuk komunikasi risiko yang dilakukan dengan cara memberikan informasi dan edukasi, melalui dua sisi ini masyarakat jadi mengetahui apa yang bisa dilakukan. Tidak hanya memberikan informasi terkini melalui konten namun KawalCOVID-19 juga memberikan edukasi untuk membantu masyarakat memahami kondisi yang tengah dihadapi. Dengan adanya pemahaman tersebut maka masyarakat akan menyadari risiko dari permasalahan kesehatan yang tengah mereka hadapi. Sebagaimana dijelaskan oleh (Freberg et al., 2013) bahwa komunikasi risiko merupakan aktivitas membangun relasi dan pemahaman bersama dalam rangka terbentuknya kesadaran bersama akan risiko yang akan dihadapi.

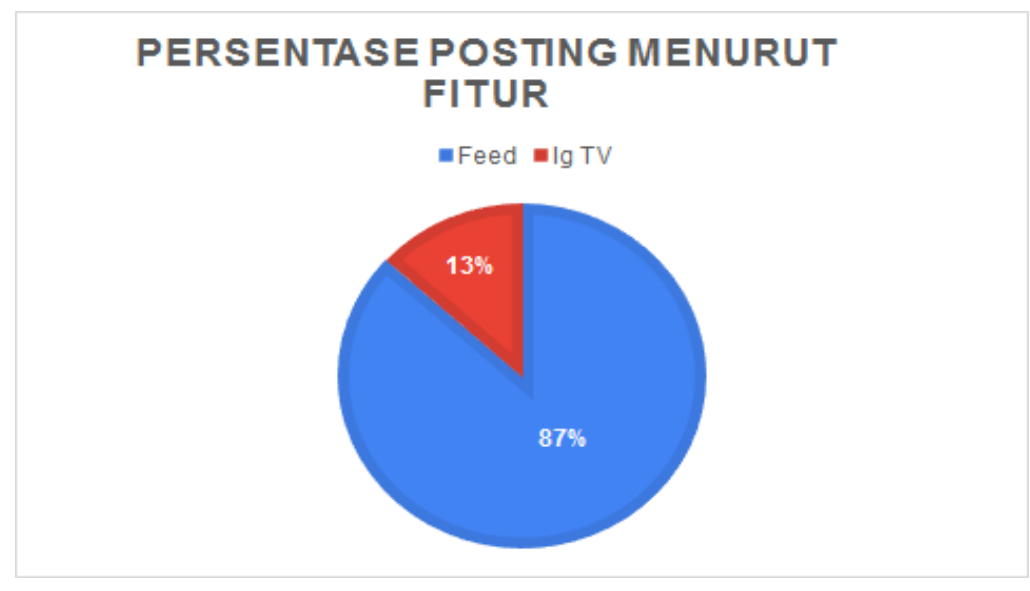

Gambar 7. Diagram Persentase Fitur Publikasi Konten (Maret - April 2020)

Berdasarkan Gambar 7 diagram diatas, sebanyak $87 \%$ konten disampaikan melalui fitur Feed Instagram, dan sisanya sebanyak $13 \%$ disampaikan melalui fitur Instagram TV (IgTV). Lebih banyak post yang dilakukan melalui fitur feed karena medium Instagram memiliki fitur utama dalam melakukan post menggunakan fitur tersebut. Konten yang ditampilkan melalui fitur feed dapat membangun komunikasi dengan masyarakat luas, karena dalam fitur feed dapat memposting berbagai bentuk misalnya infografis, gambar dan juga video singkat. Selain itu post yang dilakukan melalui fitur feed juga dilengkapi caption yang berfungsi menjelaskan gambar dan video yang di post. Selain itu pada fitur ini juga tersedia kolom komentar untuk masyarakat memberikan respon terhadap apa yang di post. Kemudian, penggunaan fitur IgTV diperuntukkan untuk konten video yang berdurasi panjang atau lebih dari satu menit. Post yang dilakukan dalam bentuk Ig Tv juga dapat diberi respon oleh followers ataupun akun lain, mengenai video yang ditayangkan. Kedua fitur ini sebenarnya saling berkaitan, karena Ig Tv akan otomatis masuk kedalam feed berbentuk cuplikan berdurasi kurang dari satu menit. Jika ingin melihat secara lengkap harus membuka langsung ke Ig Tv yang nanti sudah terhubung. 


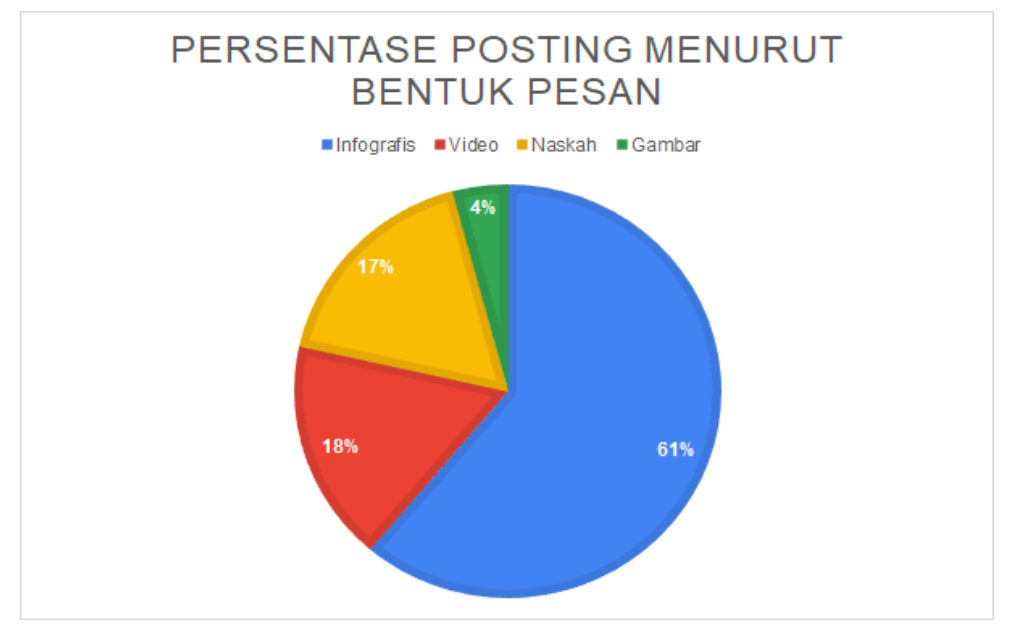

Gambar 8. Diagram Persentase Bentuk Konten (Maret - April 2020)

Selanjutnya, kami melakukan analisa terhadap bentuk konten yang digunakan dalam penyampaian pesan komunikasi risiko oleh komunitas virtual ini. Dari Gambar 8 diagram tersebut, diketahui bahwa konten yang berbentuk infografis memiliki persentase tertinggi yang sebanyak $61 \%$. Kemudian persentase terbanyak kedua adalah bentuk video yaitu sebanyak $18 \%$, dan sebanyak $17 \%$ berbentuk naskah, lalu sisanya adalah $4 \%$ yang berbentuk gambar. Infografis menjadi bentuk penyampaian pesan yang dominan digunakan oleh komunitas ini, dilihat dari tampilannya yang menarik dan interaktif tentunya menjadikan bentuk ini banyak digunakan untuk komunikasi massa guna menarik atensi dari audiens. Hal ini sebagaimana disampaikan oleh (Resnatika \& Kurniasih, 2018) bahwa infografis merupakan informasi yang dikemas dalam bentuk visual, bertujuan mempermudah orang untuk mengingat dan memahami sebuah informasi tanpa harus membaca teks panjang. Proses pembuatan infografis biasa disebut dengan beberapa istilah yang berbeda seperti data visualization, information design dan information architecture. Infografis ini ditampilkan untuk menarik minat masyarakat untuk membaca post yang ditampilkan. Kemudian, bentuk infografis yang diproduksi oleh komunitas ini memiliki beragam bentuk tampilan seperti grafik mengenai informasi jumlah kasus COVID-19, sehingga mudah dibaca oleh masyarakat dan di update setiap harinya. Infografis ini juga digunakan untuk menyampaikan konten-konten edukasi kepada masyarakat, dengan tampilan yang menarik berupa gambar-gambar animasi atau manga dengan narasi yang sederhana, sehingga dapat menarik atensi audiens dan mudah dipahami oleh masyarakat.

Dalam komunikasi risiko, terdapat enam prinsip agar komunikasi tersebut berhasil, yaitu; mengenali audiens, melibatkan pakar ilmiah, menciptakan keahlian dalam berkomunikasi, menjadi sumber informasi yang dapat dipercaya, tanggung jawab bersama, dan menjamin keterbukaan (Nasir, 2013). Medium Instagram merupakan salah satu media sosial yang paling banyak diminati penggunaanya oleh anak muda. Dalam hal ini berarti audiens dari komunitas KawalCOVID-19 di medium instagram didominasi oleh anak muda. Infografis menjadi bentuk pesan yang efektif digunakan untuk menyampaikan pesan kepada anak muda, karena tampilan pesannya yang kreatif, menarik, kekinian, dan sederhana namun berisi.

Selanjutnya, konten yang berbentuk video, yang berisi pesan edukasi atau opini yang bertujuan untuk memberikan pemahaman kepada masyarakat dan juga informasi. Durasi video yang digunakan kebanyakan lebih dari satu menit. Post dalam bentuk video ini dapat menarik minat masyarakat untuk menonton karena sudah ada visual dan audio sehingga hal ini menjadi daya tarik bagi masyarakat untuk mendapatkan informasi dan edukasi.

Kemudian, konten yang berbentuk naskah. Naskah yang dibuat biasanya berisi informasi dan edukasi yang cukup panjang. Post ini biasanya merupakan konten yang berisi himbauan atau informasi. Tim relawan komunitas KawalCOVID-19 ini terdiri dari warganet Indonesia yang pro data yang sebagian berlatar belakang medis, edukasi, sains, riset, teknologi dan komunikasi massa. Prinsip komunikasi risiko seperti dijelaskan sebelumnya, menunjukkan bahwa komunitas ini dalam menyampaikan komunikasi risikonya telah melibatkan pakar ilmiah dan menjadi sumber informasi yang dapat dipercaya dan bertanggung jawab. Pesan yang disampaikan dalam bentuk naskah, berisi edukasi dan informasi yang padat dan berkualitas. Selain itu, naskah digunakan untuk menyampaikan informasi 
yang lebih detail tentang himbauan tindakan terkait virus tersebut. Terakhir adalah konten yang berbentuk gambar memiliki persentase kemunculan paling kecil yakni sebanyak 4\%. Dalam hal ini gambar yang di post merupakan gambar dokumentasi tenaga medis, yang tidak mengandung komik manga.

\section{Pemaknaan Khalayak Terhadap Komunikasi Risiko Yang Dilakukan}

Dalam penelitian ini, pemaknaan khalayak dimaksudkan pada bagaimana persepsi dan sikap warganet terhadap akun Instagram yang dilakukan gerakan peduli KawalCOVID19.id. Pemaknaan khalayak dalam penelitian ini menggunakan pendekatan analisis resepsi. Menurut (Ida, 2014), analisis resepsi digunakan untuk melihat dan memahami respon, penerimaan, sikap, dan makna yang diproduksi atau dibentuk oleh penonton atau pembaca. Asumsi dasar dari analisis resepsi adalah konsep khalayak aktif yaitu khalayak yang mempunyai kebebasan dan kemampuan untuk menerima dan membandingkan teks di media (preffered reading) dengan makna yang ada di dalam benak mereka. Menurut (Davis, 2004), pemaknaan oleh khalayak dapat dikategorikan ke dalam tiga bagian yaitu: (1) dominanthegemonic position, yaitu khalayak menerima dan mereproduksi kode teks yang sama dengan produser pesan. Pada posisi ini khalayak berpegang pada makna yang ditawarkan dalam media; (2) negotiated position, yaitu khalayak memaknai dan menerima secara luas sebagian kode teks tetapi kadang menentang atau mengubahnya sesuai dengan cara pandang, pengalaman, dan minat. Posisi ini menunjukkan adanya kontradiksi; dan (3) oppositional position, yaitu ketika khalayak mengembangkan interpretasi yang sama sekali berbeda dengan kode teks. Posisi ini terjadi ketika khalayak berada dalam situasi sosial yang berlawanan dengan kode teks dominan sehingga membuat mereka menolak teks tersebut. Dalam posisi ini, khalayak dapat mengajukan alternatif kode yang berbeda

Berdasarkan analisa yang dilakukan, terdapat tiga konten Instagram dengan jumlah komentar warganet terbanyak di antaranya, post pada tanggal 15 April 2020 dengan judul "Kalau ini cuma flu biasa, terus ngapain kami para nakes capek-capek, repot-repot, pakai baju beginian. Kami melakukan ini supaya bisa efektif selamatkan nyawa, jadi jujurlah pada kami tentang kondisi anda supaya kami bisa pulang dengan selamat ke keluarga kami”, merupakan konten yang mendapatkan respon terbanyak dari warganet. Konten tersebut dapat dilihat pada infografis di bawah ini

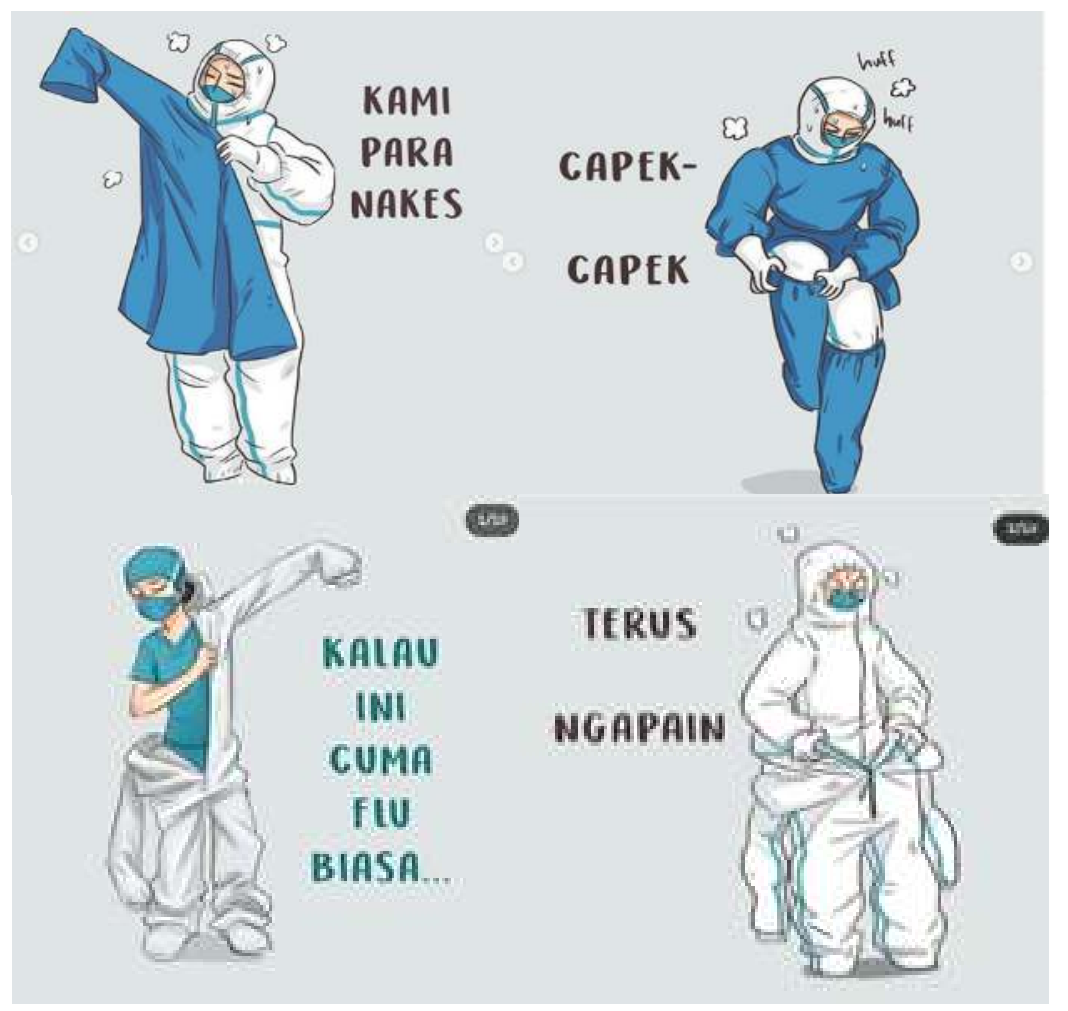

Gambar 9. Konten dengan jumlah komentar terbanyak 
Konten di atas disukai oleh warganet sebanyak 32.870 orang, 14 kali dibagikan, serta mendapatkan 221 jumlah tanggapan atau komentar. Berdasarkan Analisa yang dilakukan terhadap isi komentar warganet, pemaknaan khalayak menunjukkan bahwa sebagian besar warganet berada pada posisi dominant reading yang mana warganet tersebut menerima dan mereproduksi pesan yang sama terhadap makna pesan yang dibuat dalam konten. Sebagian besar warganet menyetujui bahwa virus COVID-19 sangat berbahaya berbeda dengan penyakit flu biasa. Mereka juga sependapat bahwasanya masyarakat diminta untuk jujur terkait kondisi kesehatan dan historis perjalanan mereka untuk meminimalisir penularan kepada dokter dan pasien lainnya di rumah sakit. Warganet sangat mengapresiasi kinerja tenaga medis sebagai garda terdepan dalam penanganan pasien COVID-19 yang harus rela memakai baju pelindung berjam-jam lamanya. Meski demikian, masih terdapat beberapa komentar yang tidak setuju dengan konten tersebut atau beberada pada posisi oppositional reading. Warganet tersebut menolak makna pesan yang disampaikan dalam konten serta memiliki persepsi sendiri karena sebuah alasan tertentu. Hal tersebut dapat dilihat dari komentar-komentar di bawah ini:

"kalau virus tidak dapat menembus kulit kenapa para nakes menggunakan baju pelindung sedemikian tebal", "sangat mengapresiasi tenaga medis tapi kenapa mereka terkesan mengeluh ya?”(@aji_bech1)

"jangan terlalu berlebihan, semua pekerjaan mempunyai resiko, meskipun dokter beresiko tinggi tetapi memiliki gaji dan tunjangan banyak sehingga keluarga tenang menunggu dirumah", "Salahin tuh menkes kenapa dulu bilang kalau corona ini adalah seperti flu biasa jadibisa sembuh sendiri”(@ucokjuntaktak)

"Tapi kata pak Menkes, kematian dari flu biasa lebih banyak daripada covid 19, katanya juga masker buat yang sakit saja, itu gimana masih relevankah?(@ucuphoria)

"barusan ada yang bilang, maaf, yang meninggal dari covid 19 "Cuma" di bawah 500 orang dari 270 juta penduduk Indonesia, gatau juga maksud beliau ngomong gitu apa.." (@wibowisz)

Berdasarkan analisa pemaknaan khalayak terhadap komentar warganet dalam konten tersebut, komunikasi resiko yang dilakukan oleh gerakan sosial KawalCOVID-19 dalam konten di atas adalah membantu memberikan gambaran kepada masyarakat betapa beresikonya tenaga medis dan keluarga terpapar virus COVID-19, oleh karenannya pasien diminta jujur terhadap kondisi kesehatan serta riwayat perjalanan mereka sehingga penyebaran virus ini dapat teratasi dengan baik. Dilihat dari banyaknya warganet yang berkomentar positif terhadap pesan yang disampaikan dalam postingan di atas maka komunikasi resiko yang dilakukan dirasa cukup efektif meskipun terdapat beberapa warganet yang berkomentar negatif. Munculnya komentar negatif dari warganet karena didasari atas pernyataan dari Menteri Kesehatan di awal bulan maret yang menyatakan bahwa virus COVID-19 ini sama halnya dengan virus flu biasa sehingga masyarakat dihimbau untuk tidak panik, serta kebijakan pemerintah terhadap pemberian diskon tiket penerbangan bagi wisatawan asing ke Indonesia. Masyarakat menganggap pernyataan tersebut sangat kontradiktif dengan pesan yang disampikan dalam konten tersebut sehingga mereka berkomentar negatif.

Konten dengan jumlah komentar terbanyak kedua di post pada tanggal 17 April 2020 dengan judul "3x gak jumatan auto kafir" (Gambar 10). Konten infografis diatas memiliki jumlah komentar sebanyak 4.459 like, serta 174 komentar. Bentuk komunikasi resiko yang dinarasikan dalam konten di atas membuat penjelasan kepada masyarakat bahwa pada masa pandemi seperti sekarang ini kondisinya sesuai dengan syarat pengecualian tidak diperbolehkan untuk sholat jumat berjamaah sesuai dengan hadits Nabi yaitu, kita meyakini bahwa shalat jumat itu wajib sehingga sewaktu situasinya tidak memungkinkan maka kita wajib menggantinya dengan sholat zuhur, pemerintah sudah menetapkan zonasi pertanda keadaan sudah darurat, serta adanya uzur berupa kekhawatiran akan keselamatan jiwa, baik jiwa kita maupun orang lain.

Konten dalam postingan tersebut mendapatkan respon yang beragam dari warganet. Sebagian besar warganet menyatakan sikap setuju dengan konten tersebut, dalam hal ini pemaknaan khalayak berada dalam posisi dominant reading karena warganet memaknai sama dengan makna yang terdapat dalam konten tersbut. Dari 174 komentar warganet, hanya terdapat 2 komentar yang berada pada posisi oppositional reading atau tidak setuju terhadap pesan dalam konten. Beberapa pernyataan warganet yang tidak setuju tersebut di antaranya, 


\section{X GAK JUMATAN AUTO KAFIR}

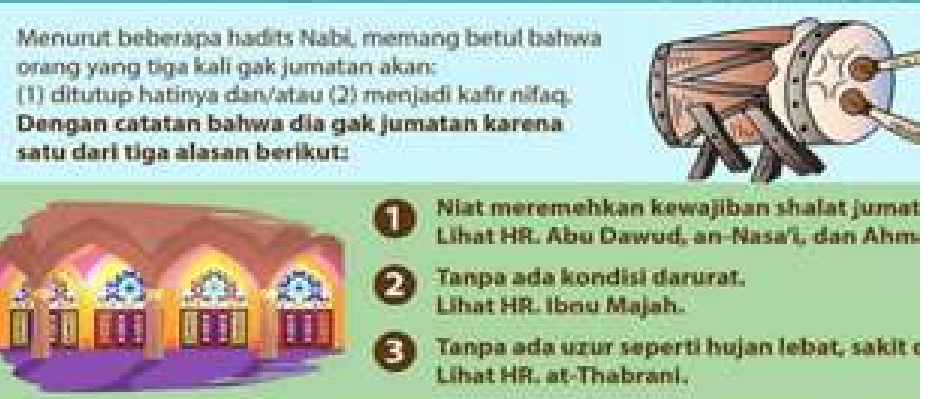

Di tengah situasi pandemi seperti sekarang. Jelas sekall kita tidak memenuhi satupun alssan di atas karena:

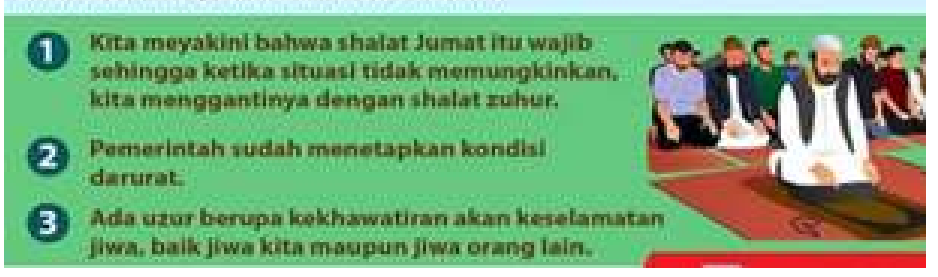

Gambar 10. Konten dengan jumlah komentar terbanyak kedua

"seharusnya postingan tersebut khusus diperuntukkan bagi masyarakat di zona merah, lanjut aja jumatannya jangan dipukul rata semuanya, masak yang digigit nyamuk tangan tapi kaki yang digaruk. Kita harus cerdas dalam menilai mana zona merah mana zona hijau " (@human.fair).

Komentar tersebut memiliki balasan sebanyak 64 kali yang mana hampir semuanya menyanggah. Beberapa pernyataan sanggahan tersebut di antaranya sebagai berikut:

"Mas nya yakin di zona hijau tidak akan tersebar wabah? Bagaimana seandainya orang dalam zona merah sholat di zona hijau? Ilmu kita ga lebih dari ulama mas, jadi tugas kita ikut apa kata ulamasaja untuksaatini" (@masmasmalas).

Alas an dipukul rata adalah karena virus ininyebarnya cepet banget dan tidak terdeteksi, dengan adanya himbauan ini peyebaran virus diharapkan melambat dan agar zona hijau tidak menjadizonamerah" (@rafitwdhyrhrj)

Komentar yang tidak setuju berikutnya adalah sebagai berikut:

"virus corona adalah makhluk Allah jadi kalau kita sholat jumat di masjid setelah itu kita terkena virus corona dan meninggal, insyaallah kita mati secara husnul khotimah oleh karenanya mari kita sholat jumat di masjid biar tidak kafir"(@nickxvuata2)

Balasan dari komentar tersebut adalah:

"Apakah anda mau sholat di tempat yang ada ularnya padahal tempat itu suci? Ular juga makhluk Allah, apakah anda yakin kalau kita digigit ular tersebut pas sholat terus kita mati maka akan mati syahid? Islam adalah agam logis, Allah memerintahkan hambanya untuk menjauhi wabah penyakit karena akan menularkan kepada orang lain yang berarti kita dzolim kepada oranglain"(@suarara)

Berdasarkan analisa pemaknaan khalayak di atas, komunikasi resiko yang dilakukan akun KawalCOVID-19 dalam rangka pencegahan virus Covid19 dinilai berhasil meskipun terdapat beberapa warganet yang masih memiliki persepsi berlawanan. Melalui pesan konten yang terdapat dalam infografis di atas, Gerakan Peduli KawalCOVID-19 mampu meyakinkan warganet bahwa kondisi sekarang (masa pandemi) sangat relevan dengan hadits Nabi tentang pengecualian orang yang tidak wajib mengikuti sholat jumat di masjid dan menggantikannya dengan sholat zuhur di rumah. Oleh karenanya, anggapan orang tentang seorang muslim yang tidak melaksanakan sholat jumat tiga kali berturut-turut di masa pandemi COVID-19 dianggap kafir dapat terbantahkan. 


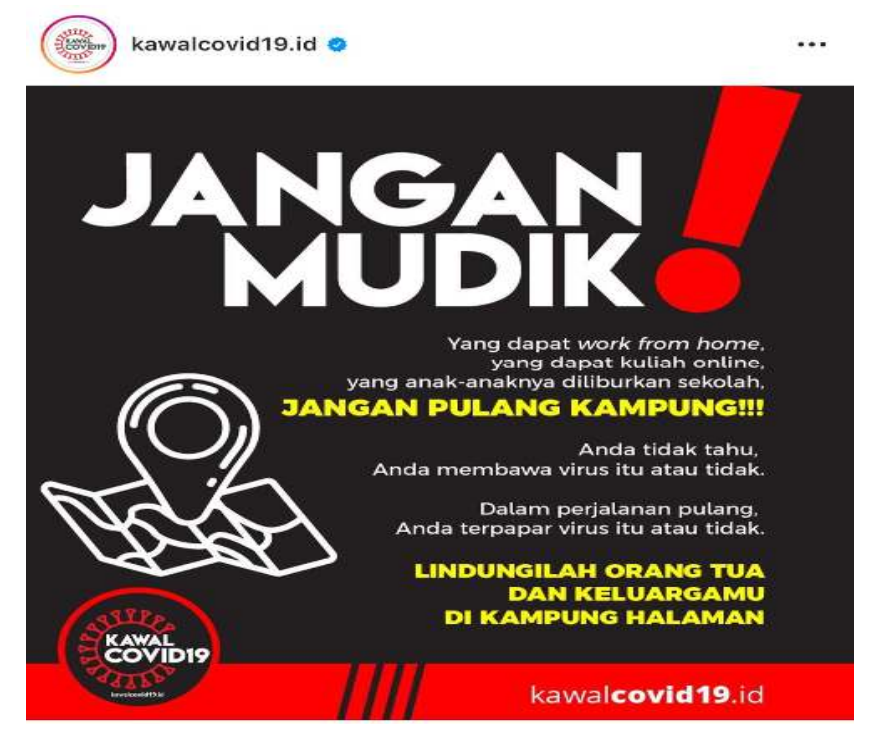

Gambar 11. Konten dengan jumlah komentar terbanyak ketiga

Konten yang di post pada tanggal 14 Maret 2020 yang berjudul "Jangan Mudik" ini mendapatkan 2.062 Likes dan 107 Comments dari warganet. Pada konten ini, narasi yang diberikan adalah seruan untuk tidak pulang kampung bagi masyarakat yang bekerja dari rumah, kuliah online, dan diliburkan sekolah, karena kita tidak tahu bila terpapar virus selama perjalanan pulang tersebut, maka dari itu lindungilah orang tua dan keluarga di kampung halaman dengan tidak mudik. Maraknya masyarakat yang memanfaatkan adanya seruan work from home dan belajar di rumah untuk melakukan mudik atau pulang kampung ke halaman menambah banyaknya kasus tiap harinya. Maka dari itu, KawalCOVID19 membuat konten berisi edukasi tersebut untuk menyeru masyarakat.

Konten ini mendapatkan komentar yang berlainan dari warganet, banyak yang menganggap bahwa peraturan pemerintah tidak sejalan dengan peraturan yang diberikan oleh banyak kampus. Banyak kampus menganjurkan mahasiswa untuk pulang kampung atau kembali ke rumah masing-masing, sementara pemerintah melarang hal tersebut. Banyak masyarakat menyayangkan hal tersebut. Beberapa komentar menjelaskan alasan mengapa banyak masyarakat yang menghiraukan larangan pemerintah tersebut. Diantaranya adalah karena banyaknya masyarakat dan mahasiswa rantauan. Banyak masyarakat yang bekerja merantau ke Jakarta dan kota besar lainnya tidak memiliki pekerjaan lagi dikarenakan harus PSBB. Jika harus hidup di kota orang mereka harus membayar kontrakan dan menghidupi biaya sehari-hari. Sedangkan tidak ada pemasukan sama sekali. Setidaknya jika mereka pulang ke kampung halaman mereka masih bisa makan dan tidak perlu membayar kontrakan. Sebuah komentar yang sedikit menyindir adalah "Jangan pulang, biarkan kita mati di kampung orang" (@anggraeni_sinaga28).

Komentar ini seakan-akan mengingatkan kita bahwa jika kita sayang kepada keluarga kita di rumah, maka yuk kita bersama-sama melindungi keluarga kita di kampung dengan tetap tidak mudik dan kalaupun kita sakit setidaknya kita tidak juga menyakiti keluarga kita. Selain itu, analisa dari komentar yang diberikan warganet, sebagian besarnya menunjukkan sikap yang kontra terhadap pesan dari konten tersebut. Dalam hal ini, katagori pemaknaan khalayak atas konten ini adalah oppositional position, dimana khalayak mengembangkan interpretasi yang berbeda dengan kode teks. Berikut ini adalah beberapa komentar yang mendapatkan banyak likes dan replies dari warganet:

"kalo untuk mahasiswa yang keluarganya di kampung statemen ini cukup menyakitkan sih (haha) bagaimana kalo sakit, gmna kalo pasokan makanan berkurang krn pada heboh ngeborong," (@Dwisthy)

"kalo dikota asal lebih aman gmn dong? Ngerti kok buat anak rantauan kalo disuruh dikosan terus gausah keluargmn hidupnya? @)” (@evander_natanael)

"intinya kita bisa pulang kapan saja, dg catatan cek kesehatan sblm pulang, kita pulang dg keadaan sehat \& tidak sedang dalam keadaan sakit, so... \#janganmudik untuk orang-orang yang belum tahu kesehatan dirinya sendiri." (@shofyanshauri) 
"saya juga begitu, kosan di Bogor, sudah masuk red zone. Rumah di Jawa Tengah blum ada positif corona. Dan saya milih stay at kosan. Demi orang rumah \& demi teman-teman saya disini.Karna kalo dirumah saya makin gak bisa isolasidiri”(@lindaayutiyas)

Dari beberapa komentar tersebut, terdapat pemaknaan khalayak yang pro, kontra, dan negosiasi, namun lebih cenderung yang memberikan makna yang kontra atas pesan konten tersebut. Framing komunikasi risiko yang dilakukan oleh Gerakan sosial KawalCOVID-19 ini adalah mengikuti kebijakan pemerintah dalam hal larangan mudik. Dengan memberikan edukasi kepada masyarakat bahwa mudik membawa risiko penularan wabah yang tinggi bagi orang lain. Melihat dari respon warganet atas konten-konten yang diberikan, menunjukkan dominasi sikap khalayak yang kontra atas kebijakan-kebijakan yang diberikan oleh pemerintah dalam penanganan COVID-19 ini. Ada permasalahan public trust diantara masyarakat, media, dan pemerintah saat ini terkait kasus COVID19. Framing media memainkan peranan penting dalam menentukan pemahaman publik tentang penyakit virus yang sangat menular dan reaksi perilaku. Menurut (Indiyati et al., 2020) media massa merupakan rujukan utama masyarakat di masa pandemi karena kebutuhan update informasi terbaru sangat dibutuhkan, namun terdapat sejumlah faktor yang mendorong masyarakat untuk mempertanyakan konten media massa karena dianggap tidak cukup untuk menumbuhkan keyakinan publik. Sejumlah faktor yang mempengaruhi kepercayaan publik pada media di antaranya perubahan perilaku konsumsi media, teknik penyajian informasi yang berkembang saat ini, kecenderungan media partisan dan narasi figur publik yang kerap berbenturan dengan media. Sementara, komunikasi massa memiliki peranan sentral dalam menanggapi pandemi COVID-19 ini (Syaipudin, 2020). Selain itu, kebijakan politik oleh Presiden dalam menghadapi masalah kewarganegaraan dalam kasus penanganan kasusk COVID-19 menekankan model kebijakan politik partisipatoris dan responsif (Farid et al., 2020). Sehingga, kebijakan pemerintah yang kerap kali ada nuansa politik menjadikan sikap masyarakat semakin tidak suka atas informasi-informasi yang diberikan dan sering menimbulkan komentar-komentar yang kontra di media sosial sebagaimana yang terjadi pada penjelasan komentar khalayak di atas. Dalam menghadapi masalah kesehatan yang masif sangat disarankan agar pemerintah bisa mendapatkan dukungan rakyat, namun pemerintah gagal berkomunikasi secara efektif dalam mensosialisasikan, mendidik, dan mengkampanyekan rakyat. Oleh karena itu, orang-orang secara besar-besaran mengeluh dan merespons secara negatif terhadap pemerintah.

\section{KESIMPULAN}

Pandemi COVID-19 berdampak signifikan terhadap permasalahan sektor kesehatan dan perekonomian di Indonesia. Tak hanya itu, rendahnya tingkat kesadaran masyarakat dalam mematuhi protokol kesehatan juga menjadi masalah serius dalam rangka memutus rantai penyebaran virus COVID-19. KawalCOVID19.id merupakan komunitas sosial yang bertujuan untuk mendiseminasikan informasi yang valid dan akurat seputar virus COVID-19 ditengah membanjirnya berita bohong atau hoax yang terjadi di tengah masyarakat. Hal tersebut sebagai bentuk manifestasi komunikasi risiko yang dilakukan oleh komunitas KawalCOVID19.id dengan cara memberikan informasi, konfirmasi serta klarifikasi melalui konten-konten yang diunggah ke dalam akun Instagram KawalCOVID19.id. Beberapa konten dengan komentar terbanyak di antaranya, konten seputar himbauan kepada masyarakat untuk jujur kepada tenaga medis terhadap kondisi kesehatan serta riwayat perjalanan mereka. Dalam konten ini, komunitas KawalCOVID19 mencoba memberikan ilustrasi kepada warganet betapa tersiksanya tenaga medis saat memakai alat pelindung diri (APD) guna menghindari terpaparnya virus COVID19. Konten berikutnya adalah post dengan judul "Tiga kali tidak jumatan auto kafir" serta post "Jangan mudik". Melalui konten tersebut Komunitas KawalCOVID19 mencoba untuk memberikan klarifikasi seputar perdebatan yang terjadi di tengah masyarakat tentang fatwa Majelis Ulama Indonesia (MUI) yang menganjurkan masyarakat di zona merah untuk tidak melakukan salat Jumat berjamaah di masjid dan digantikan dengan salat Zuhur di rumah. Sedangkan postingan tentang himbauan untuk tidak mudik berisikan tentang informasi tentang betapa beresikonya seseorang apabila tetap mudik bagi keluarga dan tetangga di kampung.

Berdasarkan bentuknya, konten infografis cenderung memiliki banyak respon warganet dibandingkan postingan dalam bentuk video, naskah, maupun gambar. Sedangkan dilihat dari isi pesan yang disampaikan dalam konten, pesan yang informatif seputar himbauan protokoler kesehatan, update kasus, informasi kebijakan pemerintah, dan informasi terkait ibadah cenderung memiliki komentar yang tinggi dari warganet. Melihat kecenderungan tersebut, dapat disimpulkan bahwa warganet lebih berminat kepada pesan komunikasi yang bersifat informatif daripada edukatif. Kebutuhan atas 
informasi yang akurat dapat dipertanggungjawabkan menjadikan masyarakat paham mengenai kondisi risiko kesehatan yang tengah terjadi dan dapat membantunya dalam mengambil keputusan. Sehingga dari penelitian ini, terlihat bahwa strategi komunikasi risiko yang efektif dilakukan oleh komunitas virtual di media sosial dalam kondisi krisis kesehatan seperti ini adalah melalui penyampaian pesan yang informatif menggunakan konten-konten infografis.

Penulis menyadari bahwa masih terdapat banyak keterbatasan dalam penelitian ini yang mana hanya memfokuskan pada obyek penelitian melalui postingan di medium Instagram saja. Penulis berharap agar ke depan dilakukan penelitian sejenis dengan obyek penelitian media sosial yang berbeda seperti Facebook dan Twitter sehingga didapatkan hasil yang lebih komprehensif.

\section{DAFTAR PUSTAKA}

Abdoli, A., \& Heidarnejadi, S. M. (2020). Opportunities and challenges of social media in outbreaks: A concern for COVID-19. Ethics, Medicine and Public Health, 15, 100557. https://doi.org/10.1016/j.jemep.2020.100557

Abrams, E. M., \& Greenhawt, M. (2020). Risk Communication During COVID-19. The Journal of Allergy and Clinical Immunology in Practice, 8(6), 1791-1794. https://doi.org/10.1016/j.jaip.2020.04.012

Apuke, O. D., \& Omar, B. (2020). Fake news and COVID-19: modelling the predictors of fake news sharing among social media users. Journal of Telematics and Informatics, July, 101475. https://doi.org/10.1016/j.tele.2020.101475

Barua, Z., Barua, S., Aktar, S., Kabir, N., \& Li, M. (2020). Effects of misinformation on COVID-19 individual responses and recommendations for resilience of disastrous consequences of $\begin{array}{lllll}\text { misinformation. Progress in Disaster } & \text { Science, } & \text { xxxx, } & 100119 .\end{array}$ https://doi.org/10.1016/j.pdisas.2020.100119

Bhat, M., Qadri, M., Beg, N. ul A., Kundroo, M., Ahanger, N., \& Agarwal, B. (2020). Sentiment analysis of social media response on the Covid19 outbreak. Journal of Brain, Behavior, and Immunity, 87(May), 136-137. https://doi.org/10.1016/j.bbi.2020.05.006

Carlos, C.-G., Giordano, P.-G., \& Ludo, van A. (2020). Social media can have an impact on how we manage and investigate the COVID-19 pandemic. Journal of Clinical Epidemiology, 1-4. https://doi.org/10.1016/j.jclinepi.2020.06.028

Chakraborty, K., Bhatia, S., Bhattacharyya, S., Platos, J., Bag, R., \& Hassanien, A. E. (2020). Sentiment analysis of COVID-19 tweets by deep learning classifiers - A study to show how popularity is affecting accuracy in social media. Economics Letters, 109231. https://doi.org/10.1016/j.econlet.2020.109231

Chatterjee, R., Bajwa, S., Dwivedi, D., Kanji, R., Ahammed, M., \& Shaw, R. (2020). COVID-19 Risk Assessment Tool: Dual application of risk communication and risk governance. Progress in Disaster Science, 7, 100109. https://doi.org/10.1016/j.pdisas.2020.100109

Creswell, J. W. (2013). Research Design Pendekatan Kualitatif, Kuantitatif dan Metode Campuran (Revisi 4). Pustaka Pelajar.

Dabbagh, A. (2020). The role of Instagram in public health education in COVID-19 in Iran. Journal of Clinical Anesthesia, 65(April), 109887. https://doi.org/10.1016/j.jclinane.2020.109887

Davis, H. (2004). Understanding Stuart Hall. SAGE Publications Ltd.

Farid, M., Pancasila, P. S., \& Barat, J. (2020). Kebijakan Politik Presiden Jokowi Terhadap Masalah Kewarganegaraan Dalam Merespon Isu Global: Studi Kasus COVID-19 Peran Negara Menjadi Penting Dalam Upaya Menjawab Tantangan Kewarganegaraan. Fenomena Penyebaran Virus Corona yang Pertama Kali Ditemukan. Citizenship Jurnal Pancasila dan Kewarganegaraan, 
$8(1), 1-13$.

Freberg, K., Palenchar, M. J., \& Veil, S. R. (2013). Managing and sharing H1N1 crisis information using social media bookmarking services. Public Relations Review, 39(3), 178-184. https://doi.org/10.1016/j.pubrev.2013.02.007

Gao, J., Zheng, P., Jia, Y., Chen, H., Mao, Y., Chen, S., Wang, Y., Fu, H., \& Dai, J. (2020). Mental health problems and social media exposure during COVID-19 outbreak. PLoS ONE, 15(4), 1-10. https://doi.org/10.1371/journal.pone.0231924

Halik, A. (2013). Komunikasi massa (Pertama). Alauddin University Press.

Handini, V. A. (2018). Manifestasi Realitas Simbolik Pada Komunitas Bercadar (Analisis Netnografi Pada Komunitas WhatsApp Bercadar di Wilayah Jabodetabek). Jurnal Mediakom, 2(2), 238249. https://doi.org/http://dx.doi.org/10.35760/mkm.2018.v2i2.1895

Harlina, R., Fatimah, S., \& Setiawan, I. (2018). Analisis Jaringan Komunikasi Risiko Petani Bawang Merah: Studi Kasus Kelompok Tani Rindu Alam Desa Cikawao, Provinsi Jawa Barat. Jurnal Agrisep, 17(21), 197-206. https://doi.org/10.31186/jagrisep.17.2.197-206

Hootsuite. (2020). Digital In 2020. We are social (Simon Kemp). https://wearesocial.com/digital-2020

Ida, R. (2014). Metode Penelitian Studi Media dan Kajian Budaya (1 ed.). Kencana.

Indiyati, D., Khusnia, H. N., Muhlis, \& Chotijah, S. (2020). Media vs kepercayaan publik di masa pandemi Pendahuluan Tinjauan Pustaka. 3, 38-44.

Islam, A. K. M. N., Laato, S., Talukder, S., \& Sutinen, E. (2020). Misinformation sharing and social media fatigue during COVID-19: An affordance and cognitive load perspective. Technological $\begin{array}{llll}\text { Forecasting and } & \text { Social } & \text { Change, } & \text { 159(May), }\end{array}$ https://doi.org/10.1016/j.techfore.2020.120201

Kaya, T. (2020). The changes in the effects of social media use of Cypriots due to COVID-19 $\begin{array}{llll}\text { pandemic. Technology in } & \text { Society, } & \text { 63(August), } & 101380 .\end{array}$ https://doi.org/10.1016/j.techsoc.2020.101380

Kozinets, R. V. (2019). Netnography: Doing Ethnographic Research Online (M. Steele (ed.); 2nd ed., Nomor January 2010). SAGE Publications Ltd.

Krum, R. (2013). Cool Infographics: Effective Communication with Data Visualization and Design (1 ed.). John Wiley \& Sons, Inc.

Li, Y., \& Zhang, K. (2020). Using social media for telemedicine during the COVID-19 epidemic. American Journal of Emergency Medicine, 395, 1016-1017. https://doi.org/10.1016/j.ajem.2020.08.007

Lin, C. Y., Broström, A., Griffiths, M. D., \& Pakpour, A. H. (2020). Investigating mediated effects of fear of COVID-19 and COVID-19 misunderstanding in the association between problematic social media use, psychological distress, and insomnia. Internet Interventions, 21(June), 100345. https://doi.org/10.1016/j.invent.2020.100345

Merchant, R. M., \& Lurie, N. (2020). Social Media and Emergency Preparedness in Response to Novel Coronavirus. JAMA - Journal of the American Medical Association, 323(20), 2011-2012. https://doi.org/10.1001/jama.2020.4469

Moran, P. (2020). Social Media: A Pandemic of Misinformation. American Journal of Medicine. https://doi.org/10.1016/j.amjmed.2020.05.021 
Nabity-Grover, T., Cheung, C. M. K., \& Thatcher, J. B. (2020). Inside out and outside in: How the COVID-19 pandemic affects self-disclosure on social media. International Journal of Information Management, June, 102188. https://doi.org/10.1016/j.ijinfomgt.2020.102188

Naeem, M. (2021). Do social media platforms develop consumer panic buying during the fear of Covid-19 pandemic. Journal of Retailing and Consumer Services, 58(June 2020), 102226. https://doi.org/10.1016/j.jretconser.2020.102226

Nasir, L. (2013). Analisis Komunikasi Risiko dalam masa Tanggap Darurat Bencana Banjir dan Longsor Aceh Besar dan Aceh Jaya. Universitas Syiah Kuala.

Nasution, S., Sadono, D., \& Wibowo, C. T. (2018). Jurnal Penyuluhan, Maret 2018 Vol. 14 No. 1 Penyuluhan Kesehatan untuk Pencegahan dan Risiko Penyakit DBD dalam Manga dan Infografis. 14(1).

Niknam, F., Samadbeik, M., Fatehi, F., Shirdel, M., Rezazadeh, M., \& Bastani, P. (2020). COVID-19 on Instagram: A content analysis of selected accounts. Health Policy and Technology, xxxx. https://doi.org/10.1016/j.hlpt.2020.10.016

Oktaviani, W. F., \& Fatchiya, A. (2019). Efektivitas Penggunaan Media Sosial Sebagai Media Promosi Wisata Umbul Ponggok, Kabupaten Klaten. Jurnal Komunikasi Pembangunan, 17(1), 13-27. https://doi.org/10.29244/jurnalkmp.17.1.13-27

Parady, G., Taniguchi, A., \& Takami, K. (2020). Travel behavior changes during the COVID-19 pandemic in Japan: Analyzing the effects of risk perception and social influence on going-out self-restriction. Transportation Research Interdisciplinary Perspectives, 7, 100181. https://doi.org/10.1016/j.trip.2020.100181

Pratiwi, S. A., \& Hidayat, D. (2020). Iklan Layanan Masyarakat COVID-19 Di Media Sosial dan Perilaku Masyarakat di Jawa Barat. 1-7. https://osf.io/9j76b/

Rahmadiana, M. (2012). Komunikasi Kesehatan: Sebuah Tinjauan. Jurnal Psikogenesis, 1(1), 88-94.

Resnatika, A., \& Kurniasih, N. (2018). Peran infografis sebagai media promosi dalam pemanfaatan perpustakaan. Jurnal Kajian Informasi \& Perpustakaan, 6(2), 183-196. https://doi.org/: : https://dx.doi.org/10.24198/jkip.v6i2.15440

Samatan, N., Fitriani, D. R., Ohorela, N. R., Gunadarma, U., \& Raya, J. M. (2017). Konstruksi Pendidikan Virtual: Studi Netnografi Pembelajaran Pada Facebook. Prosiding Konferensi Nasional Komunikasi Ikatan Sarjana Komunikasi Indonesia, 01(01), 686-691. https://doi.org/http://dx.doi.org/10.25008/pknk.v1i1.74

Syaipudin, L. (2020). Peran Komunikasi Massa Di Tengah Pandemi Covid-19. Kalijaga, 2(1), 14-34.

Triyaningsih, H. (2020). Efek Pemberitaan Media Massa terhadap Persepsi Masyarakat Tentang Virus Corona (Studi Kasus; Masyarakat di Pamekasan). Meyarsa Jurnal Ilmu Komunikasi dan Dakwah, 1(1). https://doi.org/http://dx.doi.org/10.19105/meyarsa.v1i1.3222

Tsui, E., Angeles, L., Rao, R. C., Arbor, A., Carey, A. R., Feng, M. T., \& Provencher, L. M. (2020). Using Social Media to Disseminate Ophthalmic Information during the \#COVID19 Pandemic. Ophthalmology, 127(9), e75-e78. https://doi.org/10.1016/j.ophtha.2020.05.048

Wang, Y., Hao, H., \& Sundahl Platt, L. (2020). Examining risk and crisis communications of government agencies and stakeholders during early-stages of COVID-19 on Twitter. Computers $\begin{array}{llll}\text { in Human } \quad \text { Behavior, } 114 \text { (June 2020), } & \end{array}$ https://doi.org/https://doi.org/10.1016/j.chb.2020.106568

WHO. (2020). Risk communication. World Health Organization. https://www.who.int/riskJurnal Komunikasi Pembangunan | Vol. 18 (02) 2020 | 192 
communication/background/en/\#: : text=Risk communication refers to the,themselves and their loved ones.

Wicandra, O. B. (2006). Peran infografis pada media massa cetak. Jurnal Nirmana, 8(1), 44-49.

Zhong, B., Huang, Y., \& Liu, Q. (2021). Mental health toll from the coronavirus: Social media usage reveals Wuhan residents' depression and secondary trauma in the COVID-19 outbreak. Computers in Human Behavior, 114(August 2020), 106524. https://doi.org/10.1016/j.chb.2020.106524 